\title{
研究論文
}

\section{背負い板形画肩掛け式ベルトによる 中山間地水田畦畔刈払い作業負担の軽減}

\author{
唐橋 需・三竿善明 \\ 鳥取大学農学部
}

Reduction in Working Strain by Using a Hanging Weed Cutter with Two Rubber Ropes from Shoulder Belts Attached to a Back - Mounted Board to Clear Weeds in the Levee of Paddy Fields in Hilly and Mountainous Areas

Motomu Karahashi, Yoshiaki MisaO

Faculty of Agriculture, Tottori University

\section{1. 緒言}

水田畦畔の草刈には，天端と法面を同時に刈る 歩行型の二面式草刚機や，天端等を作業者が歩行 しつつ法面を走行する草㺫機を手で支持する方式 のものが使用されたり，車輪式草㺫機（石束ら 2003）が開発・市販されている。しかしながら, 現状の中山間地域における水田畦畔等の草刈作業 には，手持ち式であるため作業負担は大きいが， 何処でも誰でもどのような草でも使えて, 軽量で 自由な作業姿勢を取れて安価であるループハンド ル式刈払機（図1）が使用に適していると思われ る.

そこで，平成 $14 \sim 16$ 年にこの手持ちループハ ンドル式刈払機の作業姿勢の自由性を損なうこと のない作業負担軽減技術の創出に取り組んだ。そ の結果, 平成 14 年に 2 本のゴムロープで, 背負い 板形両肩掛け式ベルトの両肩直下の胸元から V 字状に刈払機の棹を支持する方法（以下，両肩掛 け式と称す）を試作開発し，以後改良を加えた。

また, 平成 15 年に両肩掛け式による作業負担軽 減効果の評価を試みたが，作業能率（または作業

平成 18 年 4 月 17 日受付

平成 18 年 11 月 11 日受理

Corresponding author

唐橋 需 Motomu KaraHASH

于 680-8553 鳥取市湖山町南 4 丁目 101

Minami 4-101, Koyama-cho, Tottori, 680-8553

E-mail : karahasi@muses.tottori-u.ac.jp

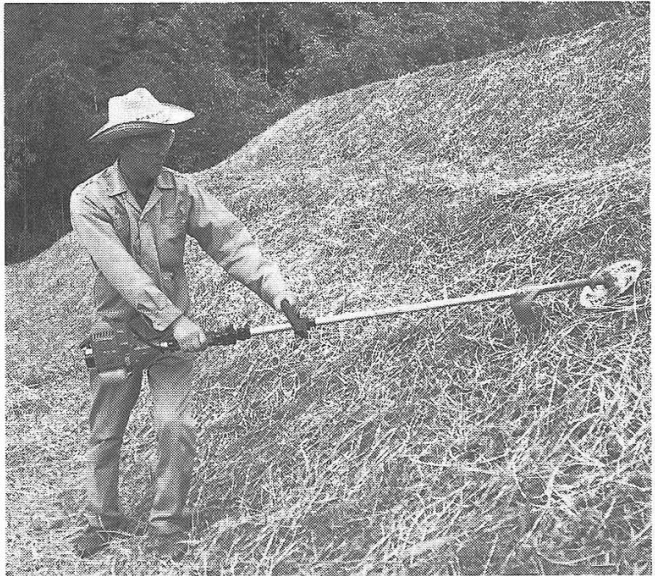

図１ループハンドル式刚払機 (手持ち式作業状態)

量）と心拍数増加率の関係がよく分かっていない ために，ループハンドル式，背負い式等の機種や 手持ち、ゴムロープ支持等の作業方法による作業 負担軽減効果の比較が難しいことが知られた，そ こで, 雑草の生育密度や地表面の凹凸等の影響を 避けて, 作業能率と心拍数増加率の関係を明らか にするため, 平成 16 年春季に室内動作実験を行っ て検討した，その結果から心拍数増加率と，㺫払 機振り上げ幅及び振り上げ下ろし 1 回当たり歩行 距離と動作速度（秒／回）から換算した $10 \mathrm{a}$ 当た り所要作業時間 (h/10a) との相互関係を求め, 次いで現地作業実験を実施した。 


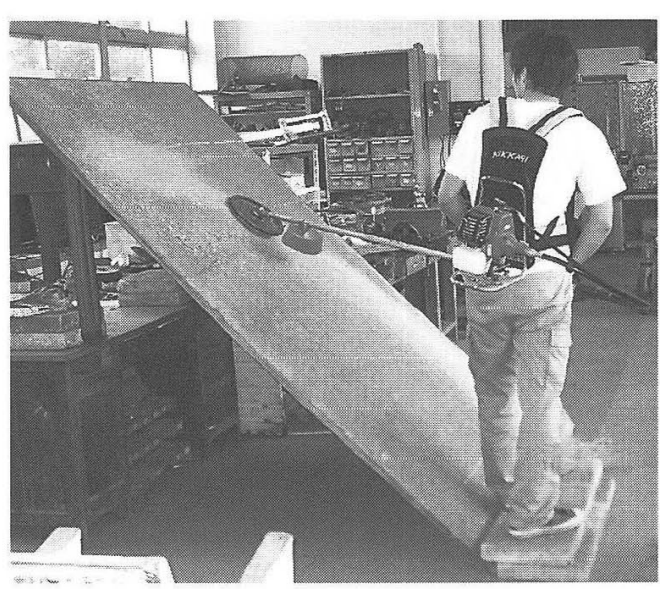

図 2 室以動作実験（背負い式刈払機）

しかしこのような相互関係を明らかにするた めには，累乗近似曲線を求めるための漸近線を知 ることが必要と分かった。 そこで, 平成 17 年に漸 近線測定実験を実施した。

なお，作業能率とは一般に 1 時間当たりに処理 できる作業量で表すか，または単位面積当たりに 必要な所要作業時間で表すが（世良田和寛 1999）。 ここでは作業能率として後者を採ることとし，以 下，作業量と区別するために作業時間と称するこ とにする，また，単位面積としては，わが国で通 常用いられる 10a とすることにする.

本研究は, 開発した両肩掛け式作業方法の作業 負担軽減効果を明らかにする。 なお，作業負担軽 減効果については漸近線測定実験, 室内動作実験 及び現地作業実験より得られる，同一作業者によ る 10a 当たり所要作業洔間と心拍数増加率の関倸 を表す累乗近似曲線間の差で行うこととした。

\section{2. 実験方法}

1) 背負い板形両肩掛け式ベルトの開発

作業姿勢の自由性を損なうことなく, 手持ち式 刈払機の作業負担を軽減する方法を考案するため, 種々の刈払機支持用ベルトを供試して検討した。

その結果, 背負い式刚払機に使用されているエン ジン搭載用背負い板式ベルト（図 2 ）に, 付属の 片肩掛け用ゴムロープを両肩掛け用の 2 本にして 取り付ける方法に可能性が見出された(図 4)。こ の方法による試作の要点は，エンジン等を除去し た背負い式のものでは両肩掛けベルトが閉じてい

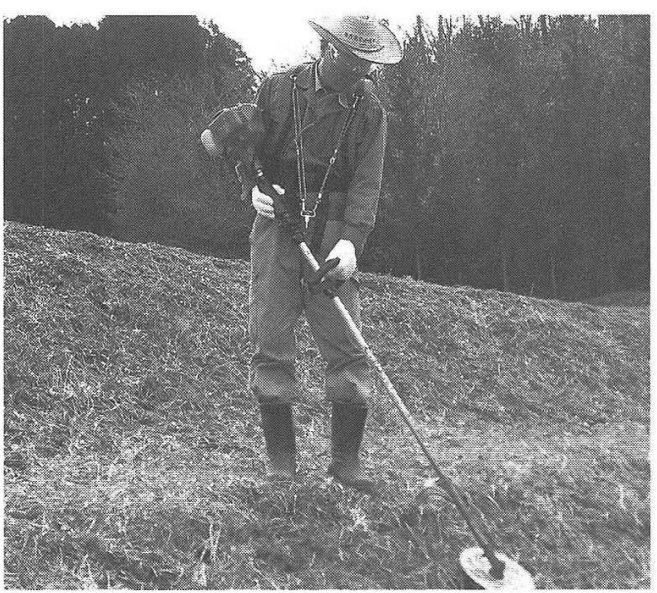

図 3 畦畔法面の下向き刈（両肩掛け式作業）

るので，刏払機を作業者の前側で吊るした時に背 負い板が引き上げられて首が圧迫されるのを解決 することであった．

次に, 両肩掛け式の場合は 2 本のゴムロープの 先端にあるフックの操作が 2 回になるが，棹への 取り付けは 1 回の操作ですむようにして，面倒さ が少なくなるように改良した(図 3，作業者中央付 近にあるフック留め具を追加した)，更に，刏払 機の質量が $6 〜 7 \mathrm{~kg}$ になると，それまでの両ゴ ムロープ共一重方式(図 4 : 肩から伸びているロー プが両方共一重である）では棹が前下方に押し出 されてしまうので，作業者右側のゴムロープを二 重式に改良した（図3，図6）.

\section{2 ) 漸近線測定実験}

作業時間（h/10a）を $\mathrm{x}$ 軸に, 作業負担を表す 心拍数增加率（\%）を $\mathrm{y}$ 軸に取った時の, 両軸方 向への漸近線を求めた， $\mathrm{x}$ 軸方向への漸近線とは, 作業時間が極限的に大きくなった時, 即ち, 作業 能率あるいは作業量が極限的に小さくなった時で あるので, 室内及び野外（現地）において作業姿 勢を取って静止した時の心拍数増加率を測定した また，y軸方向への漸近線とは，作業時間が極限 的に小さい時, 即ち, 作業量が極限的に大きい時 であるので，室内及び現地において限界と思われ る高速度で刈払機を振った時の作業時間を測定し た.

室内実験ではエンジンを停止し，現地実験では エンジン及び刈刃を高速回転させて心拍数を測定 


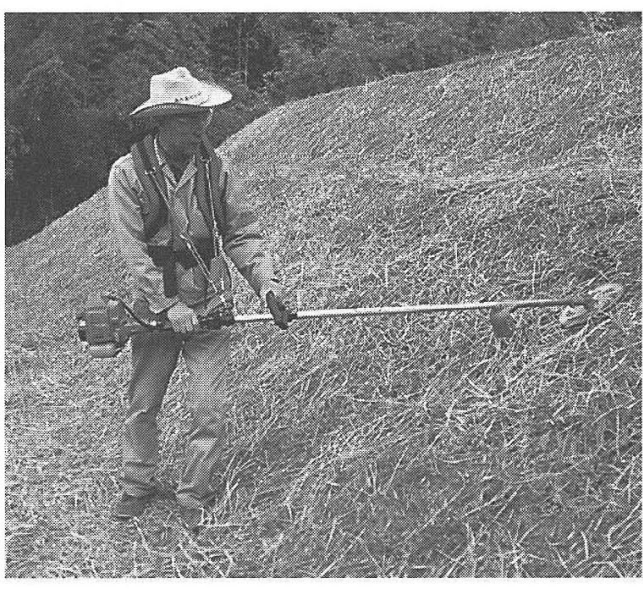

図 4 畦畔法面の上向き刈上げ (两肩掛け式作業)

した。また，後述する実験に合わせて振り上げ幅 は $1.8 \mathrm{~m}$ に設定するとともに, 1 振り当たりの掛け 幅（歩行前進距離）を $17 \mathrm{~cm}$ として換算または修 正した.

なお，実験期間は平成 17 年 10 月中旬であった。

\section{3 ）室内動作実験}

室内動作実験は，ボードを約 $45^{\circ}$ の角度に立 てかけて,これに沿ってエンジン停止状態の刚払 機を一定速度で斜面長 $1.8 \mathrm{~m}$ 分だけ振り上げて下 ろすという方法で行った(図 2). 上下速度は超低 速（5.5 秒／回, 5.0h/10a), 低 速 (4.4 秒/回, $4.0 \mathrm{~h} / 10 \mathrm{a})$, 中 速 (3.3 秒/回, 3.0h/10a), 高速 (2.2 秒 / 回, 2.0h/10a) 及び超高速（1.65 秒/回, 1.5h/10a)の 5 段階とした。 ここで, 各上下速度に 対応する作業時間は次のようにして算出した。法 面の刈幅は通常 $1.80 \mathrm{~m}$ が拈よその上限であり，ま た，刚払機のマニュアルによれば刚刃の直径（供 試機では $255 \mathrm{~mm} ）$ の $2 / 3$, 即ち $17 \mathrm{~cm}$ が 1 振り 当たりの適当な掛け幅（進行距離）とされている. よって, 1 秒 / 回は作業時間 $0.91 \mathrm{~h} / 10 \mathrm{a}$ に換算され る.

なお，振り上げ・下ろしの回数については，超 低速, 低速及び中速では作業時間が 22 分程度にな るように，また，高速及び超高速では 400 回（目 標とした所要時間では 14 分 40 秒及び 11 分 00 秒) とした。

実験期間は平成 16 年 5 月中旬であった。

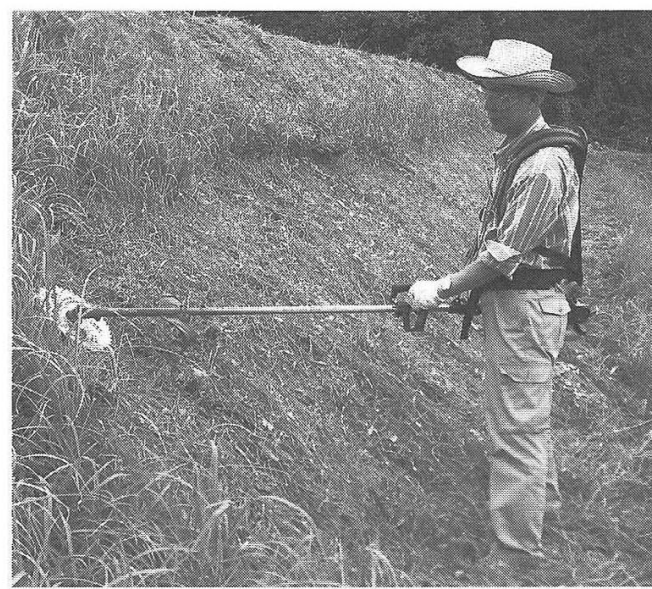

図 5 畦畔法面の上向き刈下ろし (両肩掛计式作業)

\section{4 ）現地作業実験}

実験に供した鳥取県内山間地棚田畦畔は，最上 方から数えて第 1 ～段目にあり，1列の法面か ら成る第 4 段目以外は 3 列の法面を有する(図 4 ) 3 列の法面から成る畦畔の場合, 上から順に天端, 法面，小段，法面，小段，法面，法先小段となっ ている。これら法面の傾斜角は $30 \sim 50^{\circ} ， 3$ 段 $\times$ 3 列 $\times 3$ 点平均 $43^{\circ} \pm 4^{\circ}$ である.

畦畔の草刈は，天端及び小段の(1)水平面刈，天 端及び小段を歩行しつつ行う法面の(2)下向き刈 (図 3 : 下を向いて则払機を左右に振って则る), 小段を歩行しつつ行う(3)上向き刈の組み合わせで 行われる，上向き刈には，刈払機を振り上げる時 に刈払う刈上げ（図 4 ：法面の下から上へ振り上 げているところ）と，振り下ろす時に刈る刈下ろ し（図 5 : 法面の上方から刚払機を下ろす時に刈 る，上向き刈上げの時とは身体の向きが逆にな る）の二つの方法がある。余り無理のない上向き 刈時の刈幅は $1.8 \mathrm{~m}$ 程度, 下向き刈時の刈幅は, 腰 を曲げずに楽に作業する条件では $0.7 \mathrm{~m}$ 程度で あったので，㺫幅をそれらに合わして設定した。 現地では法面長が $3 \mathrm{~m}$ 程度になると, 途中に狭い 歩行路が付けられることが多いので，上記の設定 は農家の作業実態にほぼ当てはまっていると考え られる。

以上の刚払い作業方法を種々の作業速度で行っ て，作業時間と心拍数を測定した.

なお，主な実験期間は平成 15 年 8 月，平成 16 年 $8 \sim 10$ 月，平成 17 年 10 月であった。草生は 
ススキ主体で, 生育密度はやや粗〜密, 草丈は平 均で約 $40 \sim 90 \mathrm{~cm}$ のものが分布しており不均一で あった。

\section{5 ）供試機及び使用法}

供試機は表 1 のと抢りである。これらの機種を 用いて実験に供した使用法は，次のとおりである.

A 手持ち式:ループハンドル式刚払機を両手だ けで支持する(図 1)。作業負担が大きくなって も，斜面で自由な作業姿勢を取れることを重視 した方式と思われる。

B 両肩掛け式:背負い板形両肩掛け式ベルト（図 6 , 質量約 $0.9 \mathrm{~kg}$ ）の 2 本のゴムロープにより ループハンドル式刚払機の保持を補助する。ゴ ムロープの伸縮性により自由な作業姿勢が損な われず，ゴムロープでほとんど刈払機が支持さ れる。

C 背負い式ゴムロープ無し及び有り：背負い式 刈払機のエンジン搭載部を背負う時には多少重 いと思うが，エンジンを切り離された棹部は手 持ち式に比べれば $2 \mathrm{~kg}$ 前後軽い. 通常の使用 状態であるゴムロープ無しの方法以外に，一層 棹を持つ力を減らすために特別に棹に回転式留 め具をはめ込んで, 市販機に付属するゴムロー プ（1 本）を取り付けるゴムロープ有りの使用 方法を加えた。

D 4 サイクル両肩掛け式：4 サイクルエンジン は 2 サイクルエンジンに比べて振動, 騒音, 燃 料消費及び排気臭が少ない点で優れるが, 出力 の割には質量が大きいので, 両肩掛け式の使用 方法にすることで重いという問題点の克服を試 みた。

なお，供試機のチップソーの直径は表 1 に示し
たとおり，4サイクル式だけが $230 \mathrm{~mm}$ で他は全て 255mm であった.

\section{6 ) 作業者}

平成 17 年度の時点で 64 歳の男性（身長 $167 \mathrm{~cm}$, 体重 53kg, 刈払機の経験 $5 \sim 6$ 年). な押, 次の 別作業者に対する測定結果を参考值として加える ことにした.

23 歳男性, 身長 $168 \mathrm{~cm}$, 体重 $63 \mathrm{~kg}$, 刏払機経 験 $2 \sim 3$ 年.

\section{7 ) 心拍数の測定}

心拍数の測定にはスポーツ心拍計（ポラールエ レクトロ社製，トランスミッタ・リストレシーバ 記録間隔 $5 \mathrm{~s}$ ，測定精度 $\pm 1 \%$ ）を使用した。

安静時心拍数は, 室内実験の場合には椅子に 座って，また，現地実験の場合は日陰に腰を下ろ して30分程度楽な姿勢を保った後, 心拍数の変動 を読み取ってその平均値とした。

本研究に抢ける作業者の場合, 安静時心拍数は 全般的に $62 \sim 68$ 拍/分であったが，夏期間日中 は $68 〜 74$ 拍/分になることがあった.

室内動作実験では，超低速一超高速の動作速度 に応じて $240 〜 400$ 回の振り上げ・下ろしを行っ て，心拍数がほぼ安定したと見られる測定值の平 均值から心拍数増加率を算出した。 その一例を表 2 に示す。

現地作業実験では, 使用できる場所が限られて おり，実刈払い作業開始後できる限り速やかに心 拍数がほほ安定するようにするため, 既刈払い場 所で 50 回以上の空振り動作を行った，その後に 作業実験に入り，目標とする動作速度に応じて 50 〜 70 回の振り上げ・下ろしを行った. 作業実験中

表 1 供試機

\begin{tabular}{|c|c|}
\hline 機種 & 主要緒元等 \\
\hline ループハンドル式 & $\begin{array}{l}\text { 排気量 } 22.6 \mathrm{~mL} 2 \text { サイクルエンジン搭載, 直径 } 255 \mathrm{~mm} \text { U 形チップソー及び中径 } \\
\text { 受け血装着, 燃料空タンク時 } 4.7 \mathrm{~kg} \text { 満タンク時 } 5.2 \mathrm{~kg}\end{array}$ \\
\hline 背負い式 & $\begin{array}{l}\text { 排気量 } 25.6 \mathrm{~mL} 2 \text { サイクルエンジン搭載, フレキシブルシャフト及びループハ } \\
\text { ンドル式棹, 直径 } 255 \mathrm{~mm} \text { U形チップソー及び大径受け皿装着, 背負い部（約 } \\
6 \mathrm{~kg} \text { ) と棹部 (約 } 3 \mathrm{~kg}) \text { の合計質量約 } 9 \mathrm{~kg}\end{array}$ \\
\hline 4 サイク & $\begin{array}{l}\text { 排気量 } 22 \mathrm{~mL} 4 \text { サイクルエンジン搭載, ループハンドル装着, 直径 } 230 \mathrm{~mm} \mathrm{U} \\
\text { 形チップソー及び小径受け皿装着, 燃料空タンク時 } 6.4 \mathrm{~kg} \text { 満タンク時 } 6.8 \mathrm{~kg}\end{array}$ \\
\hline
\end{tabular}


表 2 室内動作実験における心拍数測定結果の一例（手持ち式，高速）

\begin{tabular}{|l|c|c|c|c|c|c|c|c|c|c|}
\hline 回 数 & 20 & 40 & 60 & 80 & 100 & 120 & 140 & 160 & 180 & 200 \\
\hline 心拍数 & 94 & 90 & 84 & 80 & 86 & 86 & 86 & 84 & 84 & 83 \\
\hline 平 均 & \multicolumn{10}{|c|}{ 除 外 } \\
\hline 回 数 & 220 & 240 & 260 & 280 & 300 & 430 & 340 & 360 & 380 & 400 \\
\hline 心拍数 & 85 & 82 & 84 & 90 & 89 & 87 & 90 & 91 & 88 & 92 \\
\hline 平 均 & \multicolumn{10}{|c|}{ 除 外 } \\
\hline
\end{tabular}

備考）平均の欄は，280 回以後心拍数が安定したと判定し，400 回までの測定値（87〜92 拍 / 分）の平均 士 標準偏差が $89.6 \pm 1.6$ 拍 / 分となることを示す。 また（）内は実験時 の安静值が 64 拍 / 分であったので，心拍数増加率が $40.0 \%$ になることを示す.

表 3 現地作業実験における心拍数測定結果の一例（両肩掛け式，超高速）

\begin{tabular}{|c|c|c|c|c|c|c|c|c|c|c|}
\hline 回数 & 5 & 10 & 15 & 20 & 25 & 30 & 35 & 40 & 45 & 50 \\
\hline 心拍数 & 128 & 131 & 134 & 133 & 137 & 137 & 137 & 138 & 139 & 140 \\
\hline 平均 & \multicolumn{6}{c|}{$138.0(112 \% / 65) \pm 1.2$} \\
\hline
\end{tabular}

注）空振り 50 回後に作業実験に入った.

備考）表 2 と同様.

の心拍数を 5 回もしくは 10 回振り上げ毎に読み 取って，ほぼ安定したと見られる測定值の平均値 から心拍数増加率を算出した，その一例を表 3 に 示す。なお，作業途中で著しい回転速度の低下を 引き起こすことのないよう，エンジン回転を通常 より多少高めに設定して作業を行った.

\section{3. 結果及び考察}

1 ）背負い板形両肩掛け式ベルトの開発

開発した背負い板形両肩掛け式ベルトを図 6 に 示す．装着方法の順に開発の結果をあげると，次 のとおりである.

背負い板（1）を背中に当てるようにして肩掛 けベルト（2）に両手を通して背負う. 腰ベルト (3) は背負い板が跳ね上がらない程度に軽く締め るだけでよいので，多くの試着者において腹部へ の圧迫感を生じなかった，背負い板が背中に沿っ て曲がるものでは，両肩掛けベルトが引き下げら れて背負い板がずり上がると，その上端が首に当 たることになった，そこで，背負い板を 2 枚の合 板間に 2 本の板金が挿入されて形状が強く保持さ れる構造にした結果，後述する背中パッド（7） の効果とも合わせて，背負い板が多少ずり上がっ ても首に当たることはなかった

この背負い板に間隙約 $8.5 \mathrm{~cm}$ で肩掛けベルトが 取り付けられているので，刚払機を吊るしても首

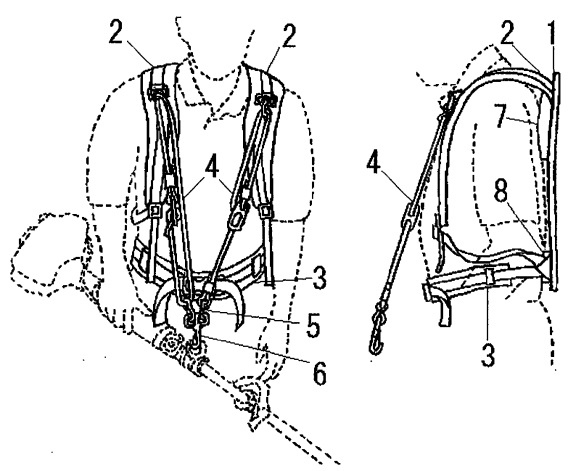

図 6 背負い板形両肩掛け式ベルト [図説明]

1 背負い板 2 肩掛けベルト 3 腰ベルト 4 ゴムロープ 5 小フック 6大フック 7 背中パッド 8 腰パッド

を圧迫することはなかった。また，肩掛けベルト は厚さ約 $2 \mathrm{~cm}$, 幅約 $8 \mathrm{~cm}$ の分厚い帯状に作られ ているので, 両肩への当たり方が柔軟であり, 留 め金具やフックによる圧迫感もほとんどなかった．

次に，作業者の身長や刚払機の質量に応じて左 右 2 本のゴムロープ (4) の長さを調節しつつ, 片方の先端にある小フック（5）を大フック（6) にかける．2 本のゴムロープで刈払機を支持する ため，刏払機の動かし方に対する自由度が著しく 大きいと思われた. 更に, この大フックをエンジ ンが始動された刈払機の回転式留め具にかけると, 
作業の準備が終了する，従って，刏払機への着脱 は肩掛け式の場合と同様にフックの操作 1 回で可 能になった.

なお，背負い板に取り付けられた背中パッド （7）と腰パッド（8）が, 背負い板が首下の骨 や背中に当たるのを防止した．両パッドともスポ ンジが封入されて厚さを当初約 $4 \mathrm{~cm}$ としていた が, 背中パッドの弾力性が低下しやすかったため, その厚さを約 $5 \mathrm{~cm}$ としてスポンジの封入量を増 加した結果, 耐久性向上の見通しを得た。 また, 使用前のゴムロープの直径は $6.1 \sim 6.4 \mathrm{~mm}$, 約 $10 \mathrm{~N} \sim 25 \mathrm{~N}$ におけるバネ定数は $10.8 \mathrm{~m} / \mathrm{kN}$ であっ た.

開発した両肩掛け式ベルトに見出された主な問 題点をあげると, 次のとおりである. (1)背中パッ ドと腰パッドにより背負い板と背中の間にかなり の隙間があるが，夏季高温時には多少暑苦しさが 感じられた，(2)作業姿勢が前かがみ状態になりや すいので, 注意を要する. (3)ゴムロープ及び背中 パッドの耐久性について今後の使用調査が必要で ある.

\section{2 ）室内動作実験}

測定結果を図 7 に示す。この図には漸近線の測 定結果と, これを用いて得られた累乗近似曲線が 示されている。 この図から以下のことが知られる.

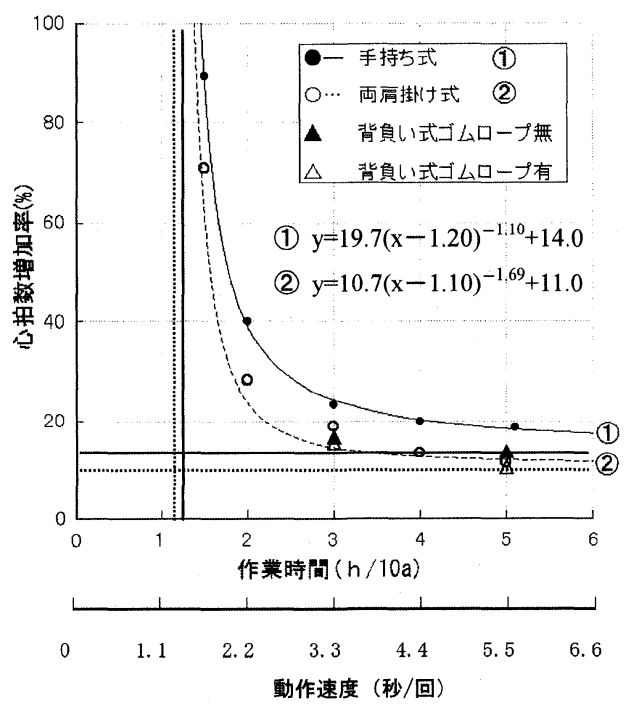

図 7 漸近線と室内動作実験結果
（1）作業時間と心拍数増加率の間には反比例 的関係がある．これは，次のことから当然のこと と思われる。

刈払機の作業負担を惹起する主要部位は手腕系 であると考えられる。手腕系に対する負担の要因 としては，刚払機の棹を持つに要する力と棹を振 る速さが支配的なものと考えられる，そこで，棹 を振る速さ，即ち 1 振り当たり所要時間（秒／回） を $\mathrm{x}$ 軸に, 心拍数増加率を $\mathrm{y}$ 軸に取ると, これら は反比例的関係になると考えられる.

（2）反比例的関係を表す累乗近似曲線を求め るためには，漸近線の測定が必要になる。この漸 近線の測定がほほ可能なことが分かった.

( 3 ) $2 \mathrm{~h} / 10 \mathrm{a}$ 以下の超高速作業では, 心拍数 増加率の変化が極めて大きくなって比較が難しく なる，例えば別作業者（図 8) に打いては，超高 速作業の○と○がほとんど重なっていた，従って， 作業負担軽減効果の比較に当たっては, 作業時間 $2 \mathrm{~h} / 10 \mathrm{a}$ 以上のところで行うのが望ましいと考え られる. ただし, 心拍数増加率であっても個人差 が生じるので，比較は同一作業者間で行う必要が ある。

(4) 心拍数増加率を累乗近似曲線間で 1.5h/10a を除外して比較すると, 両肩掛け式は手 持ち式より $7 \sim 15$, 平均 $10 \%$ 低下した. 同様に別 作業者の場合について見ると, $11 〜 12$, 平均 $11 \%$

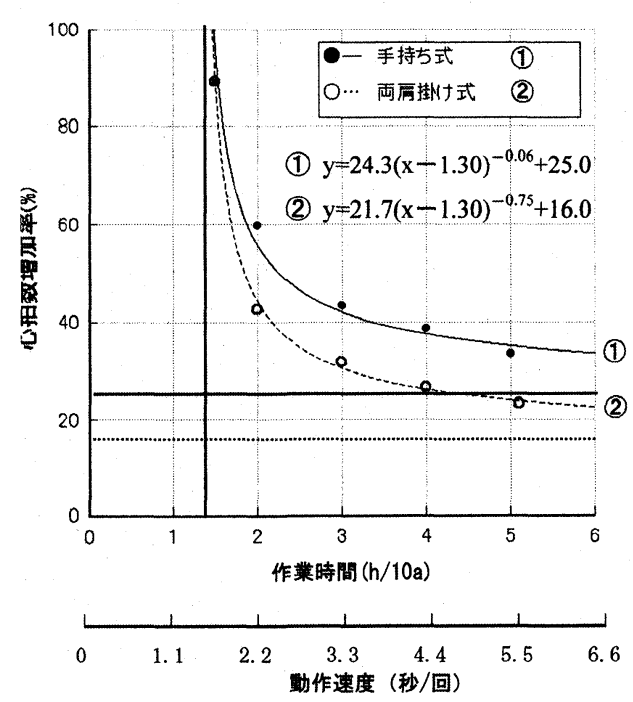

図 8 漸近線と室内動作実験結果（別作業者） 


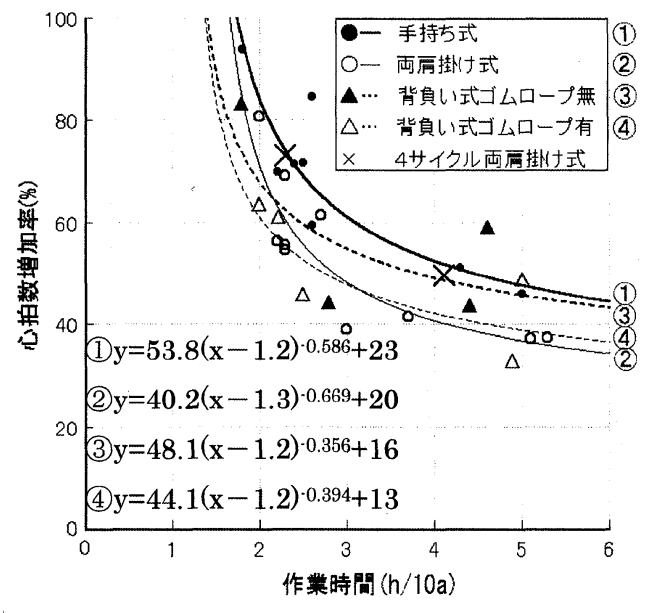

図 9 現地作業実験結果（上向き刈上げ）

の減少となっていた.

（5）背負い式は, 測定数が 2 点と少ないが, 作 業時間約 $3 \sim 5 \mathrm{~h} / 10 \mathrm{a}$ の範囲で心拍数増加率が約 8〜9\%減少していた. 従って, 両肩掛け式は背 負い式, 特にゴムロープ有りと同程度になる可能 性があると見られる。

\section{4）現地作業実験}

山間地水田畦畔において行った作業実験の結果 を図 9 〜11に示す。これらの図では, 累乗近似曲 線中に漸近線が表示されている。 ただし, 現地作 業実験における $\mathrm{y}$ 軸方向の漸近線については，刈 払機を速く振ることに集中する余り，1振り当た りの掛け幅を無視せざるを得ないので, $17 \mathrm{~cm} の$ 掛け幅で作業時間を修正する方が適当なことが知 られた。

（1）上向き刚上げ

上向き刈上げの作業方法の場合について, 機 種・使用法別に作業時間と心拍数増加率の関係を 見たのが図 9 である。これから次のことが知られ る.

測定值の変動が多少大きいが, 漸近線の測定結 果を加えると，作業時間と心拍数増加率の間には 室内動作実験の場合と同様の反比例的関係がある と考えることができる．このことは，次項で見る 刚下ろしの結果で再確認されよう.

そこで，作業時間 2〜 $5 \mathrm{~h} / 10 \mathrm{a}$ における累乗近 似曲線の差で比較すると, 両肩掛け式は手持ち式

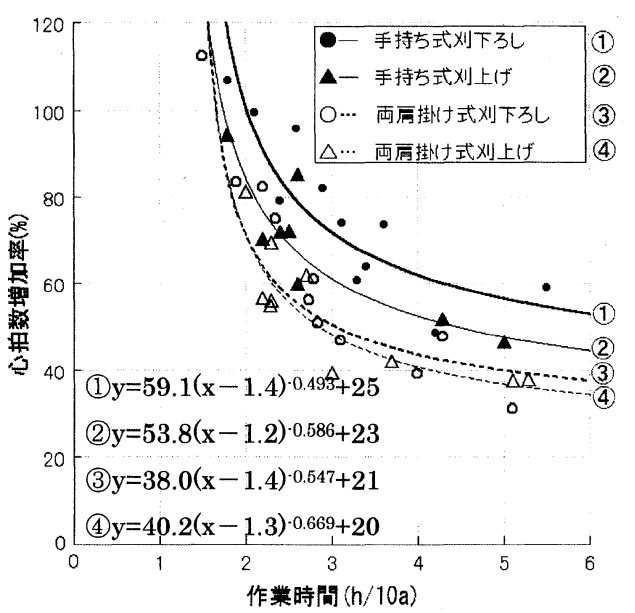

図10 現地作業実験結果 （上向き刈上げと刈り下ろし）

より $11 \sim 13$, 平均 $12 \%$ 心拍数増加率が小さく, 背負い式ゴムロープ有りと同程度であった。 また, 4 サイクル両肩掛け式は測定数が 2 点と少ないが, 2サイクル手持ち式とほぼ同程度（僅かに下回る 程度）の心拍数増加率であった。

なお，4サイクル式は 2 サイクル式より刈刃の 直径が若干小さかったが，実際の掛け幅は前者が $13 \sim 15 \mathrm{~cm}$, 後者では多くの場合に $13 \sim 17 \mathrm{~cm}$ で あり，作業時間と心拍数増加率との間の関係に チップソーの直径が及ぼした影響は小さかったと 考えられる.

(2) 上向き刈下ろし

上向き刚下ろしの作業方法を上向き刚上げの場 合と比較したのが図 10 である。これから次のこ とが知られる。

上向き刈下ろしの場合についても上向き刈上げ の場合と同様に，作業時間と心拍数増加率の間に 反比例的関係があることを確認できる。また，刚 下ろしと刚上げの累乗近似曲線が手持ち式と両肩 掛け式において，それぞれ比較的よく類似してい ることが分かる.

累乗近似曲線で比較すると, 手持ち式の場合は 刈下ろしの方が刈上げよりも明らかに心拍数増加 率が大きかったが, 両肩掛け式の場合は刚下ろし の方が刚上げよりも僅かに上回る傾向でほとんど 差はなかった，しかし，別作業者では手持ち式， 両肩掛け式共に刈上げよりも刈下ろしの方の心拍 数増加率が小さかった. 従って, 上向き刈上げと 


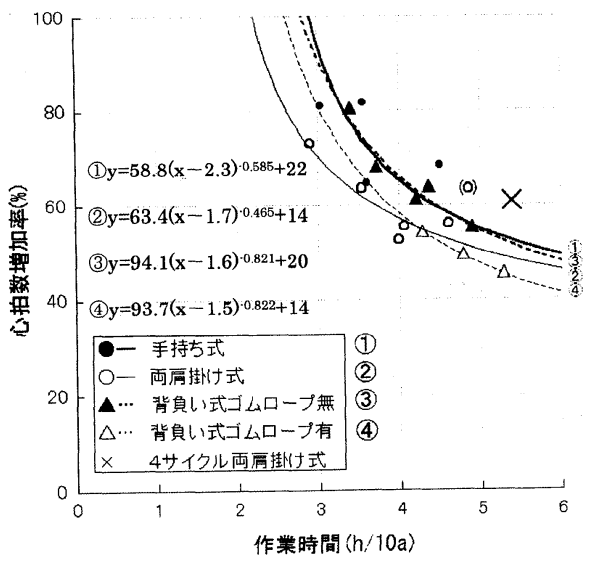

図11 下向き刈下ろし

注 1) (O)：異常点として除外する.

2 ) 手持ち式の曲線は心拍数增加率 $80 \%$ 付近の 2 点の中 点，及び $65 \%$ 付近の 2 点の中点から近似曲線を導き 出したものである.

刈下ろしの作業方法については，作業者によって それぞれ得手とする方法に違いがあるように思わ れる. 上向き刚下ろしの場合に，実験に供された 作業者では手持ち式の時に両手ともかなり振り上 げたため心拍数増加率が増大したと考えられる。

(3) 下向き朾

刈払機の棹を吊り下げて左右に振って法面を刈 払う下向き刈の作業方法について, 作業時間と心 拍数増加率の関係を見たのが図 11 である。これ から次のことが知られる。

下向き刈の場合にも上向き刈上げ及び刚下ろし の場合と同様に, 作業時間と心拍数増加率の間に は反比例的関係が認められる。これは，下向き刈 の場合にも棹を振る速さと心拍数増加率の間の関 係であることには何ら変りがないことによると考 えられる。

また，図 11 を図 9 及び図 10 と比較すると，下 向き刈は上向き刈より心拍数增加率が大きいこと が分かる．これは，下向き刈は上向き刈のように 腰を使わないで腕だけで棹を振って刈ること, 且 つ, 抵抗のかかる刚刃の位置が身体からより遠く 離れることによると考えられる。このため, 上向 き刚では通常 $3 \mathrm{~h} / 10 \mathrm{a}$ 程度で作業されるのに対し て, 下向き刚では $4 \mathrm{~h} / 10 \mathrm{a}$ 程度が適度な作業と思 われる。

そこで, $4 \mathrm{~h} / 10 \mathrm{a}$ 前後の所で図 11 の下向き刚に お漯乗近似曲線を比較すると,ゴムロープで
吊るすことでは同じ両肩掛け式と背負い式ゴム ロープ有りが同程度の心拍数増加率であった。一 方, ゴムロープを使わない手持ち式と背負い式ゴ ムロープ無しが同程度の心拍数増加率であった.

また，両肩掛け式及び背負い式ゴムロープ有りは 手持ち式及びゴムロープ無しょり心拍数増加率で 約 $7 \%$ 低減していた.

ただし，以上の下向き刈は刚幅を約 $70 \mathrm{~cm}$ とし た場合であって，それより遠い距離まで棹を下げ て刈る場合には背負い式の方が有利になると思わ れる.

なお，測定值が1点しかないけれども，質量の 大きい 4 サイクルエンジン搭載の刈払機は両肩掛 け式の使用方法であっても, 手持ち式 2 サイクル エンジン搭載刈払機より心拍数增加率が大きいと 思われる。

(4) 小段刚

測定值が 1 点ずつしかないので図を省略するが, 両肩掛け式 (3.4h/10a, 45\%) は手持ち式 (3.3h/10a, $53 \%$ ）より心拍数増加率で $8 \%$ 低減し, 手持ち式 は両肩掛け式に比較して明らかに作業負担が大き いと感じられた，背負い式はこれらよりも多少大 きかった。

（5）中山間地水田畦畔刈払い作業負担の軽減 (1)中山間地に扔ける水田畦畔の草刈では, 法面の 上向き刚作業が主要なものである。 そこで, 図 10 を概観すると，作業時間 $2.6 \sim 3.0 \mathrm{~h} / 10 \mathrm{a}$ 辺りが変 曲点になっている，即ち，供試作業者の場合には $2.8 \mathrm{~h} / 10 \mathrm{a}\left(6.0 \mathrm{~m}^{2} / \mathrm{min}\right)$ 前後の時に最も効率的に作 業できることになる。これより作業能率を上げて 作業時間を短縮しょうとすると心拍数増加率, 即 ち, 作業負担が急速に増加し, 心拍数増加率を下 げようとすると，作業能率が急速に低下して作業 時間が増大する。

(2)心拍数增加率は心拍数（拍／分）に戻せる性 質のものであるので, 同一作業者であれば単位時 間当たり酸素消費量, 従ってエネルギー消費量に 換算可能であろう。よって, 横軸に $10 \mathrm{a}$ 当たり所 要作業時間, 縦軸に心拍数増加率が取られた場合, これらの積は何らかの係数によって $10 \mathrm{a}$ 当たりエ ネルギー消費量に換算され得る数值となる. 今, 図 10 を見ると, 上記 $2.8 \mathrm{~h} / 10 \mathrm{a}$ 程度より時間をかけ てゆっくり作業しても心拍数増加率が余り低下せ ず，それより速く作業すると心拍数増加率が急激 に増大するので, $10 \mathrm{a}$ 当たりエネルギー消費量は 


\section{急激に増大する。}

(3)図 10 において上向き刚上げの場合について 見ると, 作業時間 $2.8 \mathrm{~h} / 10 \mathrm{a}$ の時, 両肩掛け式の心 拍数増加率が $51 \%$, 手持ち式が $63 \%$ ある。 供試 作業者の場合, 夏季日中で安静時心拍数が約 70 拍 / 分の時は, 心拍数が雨肩掛け式で 106 拍 / 分, 手持ち式では 114 拍/分になる.

身体的活動中の心拍数の許容限度については, 次のような報告がある。即ち, 男性の連続作業の 許容限度として, 次のように提言する：作業は, 座位姿勢で測った安静時脈拍から始め, 作業脈拍 が 35 拍になったらそこで固定すべきである(中迫 勝・石橋富和 1992)。これは 1 日 8 時間労働を通 してできる連続作業の限界であるので，刈払機の 作業では安静時心拍数からの増加量の許容限界值 は35拍/分よりは大きくなると考えられるが，そ れでも前述の手持ち式に扮ける増加量 44 拍/分は かなり大きな数值であり, 両肩掛け式の 36 拍/分 の増加量は恐らく許容限界值以下の数値であると 考えられる。

また，機械化による作業強度の軽減の程度を見 ると, 人力による稲刈りや麦刈り作業が 110 135 拍/分であるのに対し, バインダーを使うと $100 \sim 110$ 拍/分, 自脱コンバイン約 80 拍/分と なり，作業強度が大幅に削減されていることが分 かる(山地啓司 1981) とされる。これによれば, 手 持ち式 114 拍 / 分は人力刚り取りの範囲に入る可 能性のある心拍数であるが, 両肩掛け式の 106 拍 / 分はバインダー刈り並の作業負担であると思 われる。

(4)刚払機の作業はハンドルの振動の問題等が あって長時間作業が許されない. そのため, 効率 的な作業を行うことが必要になる。一方, 中山間 地に扔ける水田畦畔の面積は大きい. そのため数 日間続く作業になるので, 疲労が蓄積することの ない楽な作業でなければならない。

以上から, 開発した両肩掛け式の作業方法が中 山間地に打ける水田畦畔刚払い作業負担の軽減に 寄与する可能性は大きいと考えられる。

\section{4. 摘 要}

本研究は, 中山間地にある水田畦畔の草刈に多 く使用される手持ちループハンドル式刈払機の作 業負担の軽減を図ることを目的とする，そのため， 背負い式刚払機に使用されているエンジン搭載用
背負い板式両肩掛けベルトから 2 本のゴムロープ で V 字状に刈払機を吊るす方法 (背負い板形両肩 掛け式，以下，両肩掛け式と称す）を 2002 年に 考案した．以後 4 年間, 改良を加えつつ作業負担 軽減効果の比較方法について研究してきた，得ら れた知見を要約すると，以下のと㧍りである.

1 ) 作業時間 ( $\mathrm{h} / 10 \mathrm{a})$ と心拍数増加率 (\%)の 間には反比例的関係のあることが実証された。

2 ) 作業負担軽隇効果の比較に当たっては, 同 一作業者に打ける累乗近似曲線間の差で行うのが 望ましいと考えられた。

3 ) 両肩掛け式は手持ち式に比較して, 心拍数 増加 率で $10 \%$ 程度の作業負担軽減効果があった.

4 ) 両肩掛け式による作業負担軽減効果は, ゴ ムロープを使用した時の背負い式とほほ同等であ ると考えられた。

5 ) 以上より，両肩掛け式は手持ち式における 作業姿勢の自由性を損なうことなく作業負担の軽 減を図れることが明らかになった。

\section{謝辞}

本研究の遂行に当たって, 株)ニッカリ大西久雄 氏から多大のご協力を頂いた．ここに記して謝意 を表します。

$$
\text { キーワード }
$$

両肩掛け式, 刏払機, 中山間地, 水田畦畔, 作業 負担

\section{引用文献}

石束宣明 - 宮崎昌宏 - 高辻豊二 ·猪之奥康治 - 深 山大介・荒木环也·大西久雄（2003）：作業 感覚による草刈機の評価, 農作業研究 38 (1) ; $25-31$.

世良田和寛（1999）：(日本農作業学会編 農作業 学), 農作業の効率化技術と評価, 財)農林統計 協会, 東京, pp.36-47.

中迫勝・石橋富和 (1992)：(著者エティエンヌ・

グランジャン 産業人間工学) 許容限度, 啓 学出版(秼), 東京, pp.112

山地啓司（1981）：(運動処方のための心拍数の科 学) 農作業, (秼大修館書店, 東京, pp.119121 


\section{Summary}

In hilly and mountainous areas many looped handle type weed cutters are used for clearing weeds in the levee of paddy fields. This type of weed cutter is light, cheap, and can take free working postures. For this type of weed cutter, which we call the holding type, working strain is large because the cutter is entirely supported by both hands. Therefore, we have developed the method of hanging a weed cutter by two rubber ropes from shoulder belts attached to a back mounted board, such as has been used in the conventional shoulder type weed cutter. We call this method the "two shoulder belts" type. In this paper, we have studied how to estimate the magnitude of reduction in working strain caused by the two shoulder belts type of weed cutter.

The results are as follows ;

1) It was proved that the rate of increase in heart rate was inversely proportional to the reduction in working rate $(\mathrm{h} / 10 \mathrm{a})$.
2 ) It may be possible to estimate the magnitude of the reduction in working strain by comparing the approximate curves of exponential function in the required working time of $2 \sim 5$ $\mathrm{h} / 10 \mathrm{a}$ of the same worker.

3 ) Compared with the holding type, the two shoulder belts type decreased the working strain by about $10 \%$ of the ratio of increase in heart rate.

The two shoulder belts type weed cutter may reduce working strain to approximately that of a conventional shoulder type weed cutter with a rubber hanger-rope.

The above - mentioned results make it clear that the two shoulder belts type can decrease the working strain without spoiling the free working postures in the holding type.

\section{Keywords}

two shoulder belts type, weed cutter, hilly and mountainous areas, levee of paddy field, working strain 